\title{
TICKETING RENDSZERBEN REJLŐ LEHETŐSÉGEK - HIBAKEZELŐ SZOFTVER LÉTJOGOSULTSÁGA A DIGITALIZÁCIÓ KORÁBAN
}

\section{OPPORTUNITIES OF TICKETING SYSTEM IN THE AGE OF DIGITALIZATION}

\author{
Kis Vencel ${ }^{1}$, Böcskei Elvira ${ }^{2}$ \\ ${ }^{1}$ Pénzügyek Tanszék, Gazdaság- és Társadalomtudományi Kar, Budapesti Műszaki és \\ Gazdaságtudományi Egyetem \\ ${ }_{2}^{2}$ Pénzügyek Tanszék, Gazdaság- és Társadalomtudományi Kar, Budapesti Műszaki és \\ Gazdaságtudományi Egyetem
}

\author{
Kulcsszavak: \\ hibajegykezelés \\ digitalizáció \\ problémamegoldás \\ dokumentum menedzsment \\ költségmenedzsment \\ Keywords: \\ ticketing system \\ digitalization \\ problem-solving \\ document management \\ cost management
}

\begin{abstract}
Összefoglalás
A hiba kezelésének és megoldásának ma már számtalan módszere létezik, amely a vállalat életciklusát és digitális érettségét határozza meg. A nagyvállalatok körében leginkább a ticketing rendszer alkalmazása terjedt el, ami a szervezet méretével arányosan komplex a többi eszközhöz viszonyítva. A technológiák fejlödésével új lehetőségek nyílnak a funkcionalitást érintően is, akár más rendszerekkel történő integrálással. Kiemelkedően fontos szempont a skálázhatóság, vagyis a rendszer teherbíró képessége, amire érdemes elöre felkészülni, így a jól átgondolt struktúra a szervezet más területeire is átültethető.

\section{Abstract}

Nowadays there are plenty of tools what the firms have in order to achieve problem-solving and their chosen method can refer to the current lifecycle and digital maturity of the organization. The most common application in the case of bigger enterprises is the ticketing system. Apart from the rapid changing technologies some new opportunities can be brought to life like innovative functionalities or even application integrations. Very important aspect the scalability is as people put focus on at the first phase of implementing thus other divisions of the corporation can benefit from its transplantation.
\end{abstract}

\section{Bevezetés}

Az elmúlt években a digitalizáció gyors fejlődésének lehettünk részesei, amely az elmúlt hónapokban a világjárványnak köszönhetően, szinte valamennyi vállalkozás életébe

\footnotetext{
${ }^{1}$ Kapcsolattartó szerző. Tel.: +3614631905

E-mail cím: kis.vencel@finance.bme.hu
} 
begyürüzött, vállalati mérettôl függetlenül. A digitalizáció folyamatosan új és még újabb üzleti modelleket alakít ki, ezek értékelése és az üzleti stratégiával való összekapcsolása szoftverekkel, elemzésekkel segíthető. Vannak egyszerübb elemzési eszközök, de vannak bonyolultabbak is. [5][6]

Jelen cikkünkben egy hibakezelő szoftver múködését mutatjuk be. Ismertetjük azokat a lehetséges fejlesztési lehetőségeket, amelyek a controlling egyes folyamatait is érinthetik. $\mathrm{Az}$ eredményes gazdálkodás alappillérének tekintjük a folyamatok minél szélesebb körü digitalizációjának megvalósulását. A vállalati versenyképesség egyik kulcsa, az üzleti folyamatok ütemezése és szervezése [9]. A gazdálkodó szervezetek közötti versenyelőnyt a folyamatszervezés és optimalizálás (Business Process Management és Business Process Reengineering) jelentheti. Ezen folyamat egyik részterülete a hiba keletkezéséből adódó kiesések és erőforrás-felhasználások elosztása és szervezése.

\section{A hibakezelés életciklusai és módszerei}

A problémakezelés életciklusainak nyomon követése ma már elengedhetetlen a vállalkozások életében. Ennek eredményeként a problémamegoldási módszerek széles skálája figyelhető meg, amelyek a technikai fejlődéssel párhuzamosan folyamatosan változnak.

\section{A hibakezelés életciklusai:}

1. Probléma felismerése: Ez nem más, mint maga a hiba észrevétele. Ilyenkor nem tudatosan vesszük észre a hibákat, azaz nem hibakeresési szándékkal (kivéve, ha ez a feladatkörünk részét képezi). Fontos, hogy a szóban forgó problémát felismerjük, mert csak ez után tudunk a következő fázisba lépni és a megoldás érdekében intézkedéseket tenni.

2. Probléma azonosítása: Miután érzékeltük a probléma jelenlétét, a következő lépés az, hogy megállapítsuk a hiba mivoltát. Meg kell tudnunk mondani, hogy mi a gond, esetleg azt is, hogy mi okozza. Ez a pont szintén nagyon fontos, ugyanis, ha már tudjuk, hogy „Mi az?”, már sokkal könnyebb lesz arra is megtalálni a választ, hogy „Mit kell vele csinálni?”.

3. Megoldás keresése: Egy-egy probléma megoldására tett lépések és kombinációk száma végtelen lehet, mégis azáltal, hogy előzetesen azonosítottuk a problémát, sokkal könnyebben eljutunk arra a pontra, amit alkalmazni fogunk a későbbiekben. Miután kiválasztottuk, hogy mely módszer szerint történjen meg a beavatkozás, máris átléphetünk a soron következő és egyben utolsó lépésre.

4. Probléma megoldása és nyomon követése: Ezen szakaszban elvégezzük azokat a folyamatokat, amelyek a probléma okának megszüntetéséhez vezetnek, továbbá megbizonyosodunk arról, hogy a probléma megoldódott.

\section{A problémák, hibák megoldásának módjai lehetnek:}

1. A legalapvetóbb hibakezelési megoldás az, amikor a keletkezett problémát mi magunk korrigáljuk. A módszer használata kockázatos, mert nem lehet minden ember tisztában az összes előforduló hiba elhárításának módjával, ezért nem garantált, hogy a beavatkozás után a megszakított tevékenységünk akadálymentessé válik. A módszer másik hátránya, hogy a munkavállalónak a munkakörétől az üzemeltetési irányba kell elmozdulnia, így ez által saját szakterületéről vonja el a figyelmet, amely esetlegesen leállást generálhat.

2. A kérdések, hibák megoldását tapasztalattal rendelkező munkavállaló végzi, aki egy kézben próbálja összefogni a különböző szakterületeket. Ez az előzőhöz képest már egy fokkal hatékonyabb megoldás, azonban a hibakezelés minőségének kérdése nem teljesen biztosított. Ugyanakkor a többi munkavállalótól nem von el felesleges energiákat, a saját munkaterületükre tudnak kiemelt figyelmet fordítani. [1]

3. A kérdések, hibák megoldására szerződést kötnek egy-egy partnercéggel. Ezen szerződés tartalmazza, hogy kell-e rendszeres átvizsgálást végezni a vállalaton belül, vagy ad-hoc jellegüen, a szükség adta helyzetekben, a hiba elhárítása történik meg.

4. Hiba jelzésére ticketing rendszer alkalmazása. A ma használatos technikák közül ez a ticketing rendszer az egyik legmodernebb lehetőség. A rendszer működése azon az elven alapszik, hogy a hiba keletkezésének észrevételekor egy munkavállaló ticketet, vagy más 
szóval hibajegyet ad fel. A feladás után a hibaelhárítás kimegy a helyszínre (többnyire a munkavégzés helye a cégén belül van), és megoldja a keletkezett problémát.

A six sigma egy filozófia, amelynek lényege a vevői elégedettség és a nyereségesség növelése az által, hogy a hibák előfordulását igyekeznek minimalizálni. A szigma a matematikából a szórás jeleként ismert. A vállalkozások esetében ez azt jelenti, hogy a szigma segítségével fejezik ki a hibák előfordulását. Minél magasabb a szigma, annál kisebb a hibaarány. A módszer alkalmazható más folyamatok mérésére is, feltéve, hogy a hiba, mint fogalom előfordulhat az adott kontextusban. [2] A nagyvállalatok a fentebb felsorolt megoldások közül az utóbbiakat preferálják. A nagyvállalkozások kiemelt figyelmet fordítanak a hatékonyság növelésére, a költségek csökkentésére, a legjobb minőség biztosítása mellett.

\section{Kommunikációs csatornák szerepe a hiba feltárásában és javításában:}

a) Telefonos megoldás: A leggyorsabb módszer a telefon kézbevétele és a megfelelő kolléga vagy call-center felhívása. A cég, ahol a probléma felmerült talán a problémát gyorsan meg tudja oldani, de erről nem feltétlenül készül írásos dokumentum.

Előnye: gyorsaság

Hátránya: dokumentáció hiányában a hiba folyamata újra megismétlődhet.

b) Email/Chat: A gyakori megoldások közé tartozik az online chat vagy email alkalmazás bevonása. Nagyobb vállatoknál jól bevált, egyszerü módszer a gyors információcserére. A hálózaton belül múködő üzenetváltó alkalmazás erre kiváló technika, miután azonnal megjelenik az üzenet, amit egy logikusan strukturált felületen keresztül kezelnek. Az email küldése a chat-nél ugyan lassabb kommunikációt eredményezhet, azonban a dokumentálás és átláthatóság mindenképpen fejlettebb.

c) Chatbot: Az előbb említett technikára épül, azonban egy komolyabb informatikai háttérrel rendelkezik. A számítógépet mesterséges intelligenciával látják el, és a múltban már megtörtént (hiba)adatokon alapulnak, vagyis tapasztalati probléma megoldásnál alkalmazható. Előnye, hogy a számítógép „nem felejt”, így amely hiba egyszer már felmerült, és javításra került, azt a jövőben automatikusan kitudja javítani. Gyorsasága mellett óriási előnye, hogy nem igényel emberi beavatkozást, nem kell a fogadó oldalon ülnie ahhoz, hogy a hibát feladó segítséget kapjon. Ugyanakkor megemlítendő, hogy új, eddig ismeretlen problémákat nem tud megoldani, csak azokból tud következtetni, amelyek az adott időpontig felmerültek.

d) Jegyfeladás: Ezen technika egyik lehetséges eszköze a ticketing rendszer, amely az üzemeltetést köti össze a vállalkozás különböző területeivel, egységeivel. A munkavállaló egy előre kialakított felületen a felmerült hibáról értesíteni tudja a hibaelhárításban érintetteket, akik a különböző opciókat is figyelembe véve a probléma helyszínére érkezhetnek (amennyiben ez szükséges) és megoldják azt.

e) Ticketing rendszer: A rendszer használatának menete:

1. Probléma észlelése: A munkavállaló észreveszi a problémát

2. Probléma azonosítása: A probléma azonosítást követően a munkavállaló eldönti, hogy meg tudja-e oldani (ebben az esetben teendő nincsen) vagy szakember bevonása szükséges

3. Szakember értesítése:

- A munkavállaló a hiba specifikálásával felad egy ticketet (magyarul jegyet) az üzemeltetésnek (a ticket-feladás történhet email-en keresztül, call-centeres megkereséssel és egyéb más megoldással is);

- A jegyfeladásról az illetékesek értesítést kapnak és megjelenik náluk elvégzendő munkaként;

- A rendelkezésre álló feladatok és idő függvényében a hibakezelő a helyszínre érkezik és elhárítja a hibát;

- A munka elvégzésekor a rendszerben ezt az eseményt rögzítik;

- Optimális esetben a „megrendelő” elfogadta a hibakezelést, a jegyet lezárják, így a folyamat a végéhez ér. 


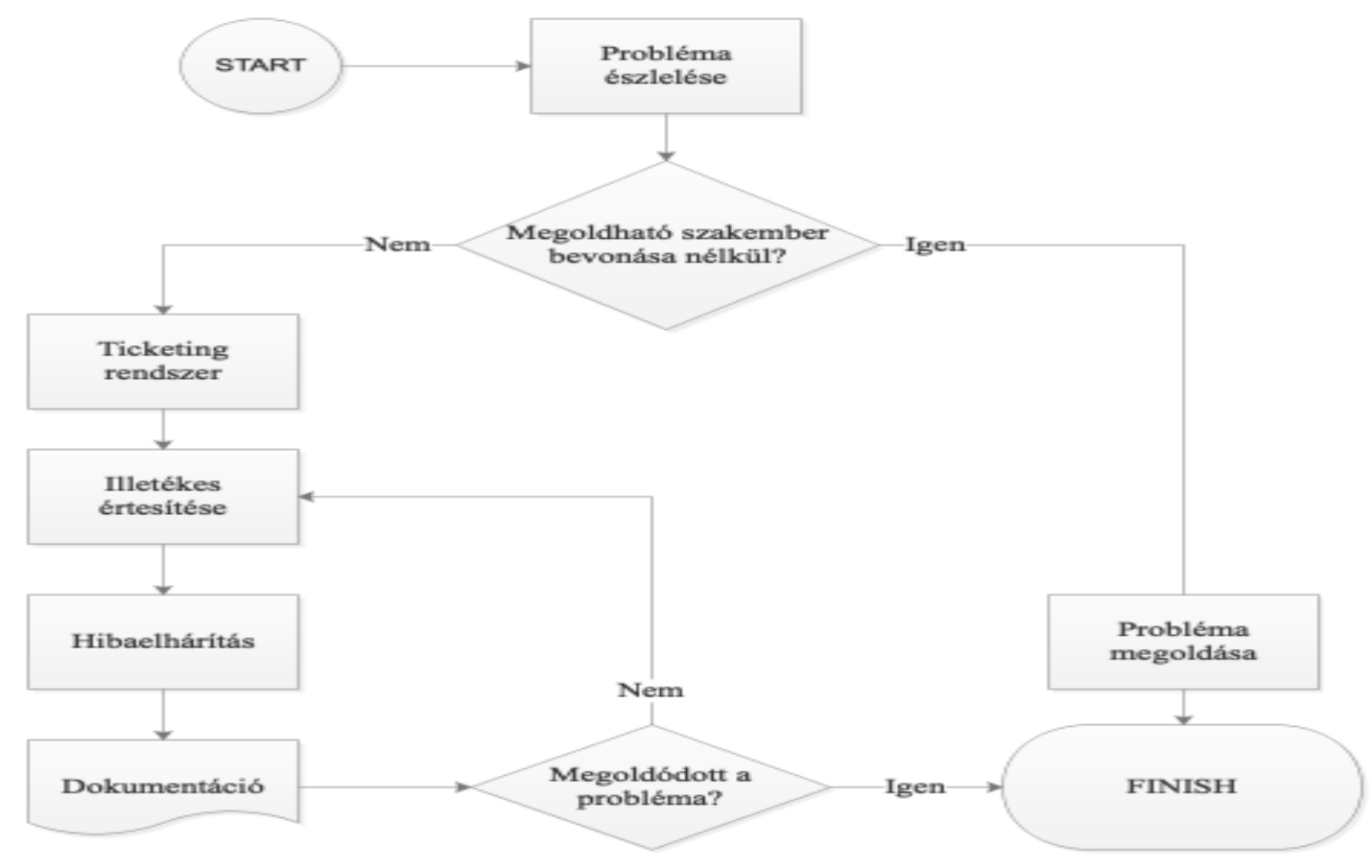

1.ábra. Hibajegy feladásának menete

Saját forrás: Ticketing rendszerben rejlő lehetőségek - hibakezelő szoftver létjogosultsága a digitalizáció korában

A jegyet feladónak adódhat olyan lehetősége, hogy a hibaelhárítás menete értékelhető legyen, meghatározott szempontok alapján. Minőségbiztosítás szempontjából elengedhetetlenül fontos mozzanat, mert így mérhető a megelégedettség mértéke.

\section{Ticketing rendszer előnyei:}

- Alkalmazása szervezetté, eredményessé és fókuszálttá teszi a problémamegoldást.

- Segítségével nyomon lehet követni a hibák típusait, azok esetleges következményeit, hatásait.

- A feladó folyamatosan látja a hibakezelés státuszát (elkezdtek már rajta dolgozni, vagy még nem vették elő, vagy éppen már le is zárták).

- Valamennyi lépés rögzítve van, utólagosan visszakereshető (szervízkönyvként funkcionál: amennyiben egy eszköz javításánál korábban már történt jegyfeladás, akkor nyomon lehet követni, hogy mi volt a probléma, továbbá annak megoldásának módját. A szoftver minden egyes esetnek ad egy azonosítót, ami végigkíséri a folyamat minden lépésén.

\section{Teljesítménymutatók:}

A rendszer múködtetéséhez nélkülözhetetlen olyan mutatószámok meghatározása, amelyek iránymutatást adnak a teljesítményre vonatkozóan. Ezek a mérőszámok a riportok készítéséhez kulcsfontosságúak, mivel a hibaelhárítással foglalkozók teljesítménye így mérhető, továbbá segítségükkel és elemzésükkel fejleszthetők az adott üzleti folyamatok. [7]

- Service Level Agreement: Célja, hogy osztályokba soroljuk a problémát, annak nehézségi foka szerint. A „nagyon magas” besorolás lehet az ügyfelet érintő vagy vállalaton belül több egységet érintő hiba. Ezen problémák elhárítását a legmagasabb prioritásként kell kezelni.

- Maximum process time: Ez az az idő, ami rendelkezésükre áll arra, hogy a tickettel foglalkozzanak és egy adott határidőn belül megoldják. A korlátozott határidő a hibaeset prioritásától függ, így esetenként eltérő lehet. 
- Reopened: Újranyitottnak tekinthető az a ticket, aminek a megoldására egyszer már tettek próbálkozást, az viszont nem müködött megfelelően, így a ticket feladó nem fogadta el megoldásként és a ticket újra előkerül.

- First Time Right: Amennyiben a ticket megnyitása után rögtön helyes megoldás kapnak, azaz pontosan a reopened csoport ellentéte.

- Postive Call Closure: A sikeresen megoldott hibaesetek számát mutatja. Az a megoldás deklarálható sikeresnek, amelyet a hibát bejelentő elfogadja.

- Expired: A ticket megoldása a rendelkezésre álló időkereten túlfutott.

\section{Múködést támogató funkciók:}

- Tervezés: Az alkalmazás fejlesztésénél is elengedhetetlen a tervezés folyamata, amely kiterjedhet a front-end-et és back-end-et érintő tervekre, vagy a felhasználó felülethez, folyamat- és adatmodellezéshez kapcsolódó elemek végig gondolására is.

- Adattárolás: Egy alkalmazás fejlesztésénél elkerülhetetlen az adatok, információk tárolása, szabályozása. Adatbázisokat vonnak be, amelyekből dinamikusan lehet adatokat kiolvasni, felvinni, módosítani.

- Biztonságtechnika: Ilyen például az autentikáció, bejelentkezési adatok (felhasználónevek és jelszavak) beküldése, amelyek mind a felhasználókat, ügyfeleket és partnerek érintik.

- Integráció: Egyrészt jelenti az adatok begyüjtését szenzorokból, másrészt az eszközök közötti együttmúködést. Ezek megkönnyítik a vásárlók és partnerek közötti, másrészt az alkalmazások közötti integrációt.

- Internet of Things (IoT): Egy igen innovatív terület az informatikában. A dolgok internete (IoT) képes gyưjteni, rendezni, szinkronizálni és megszervezni az adatokat egy gyárban vagy üzletben a különböző forrásokból. Ehhez intelligens hálózatot használnak az okos gyár, okos termékek és szolgáltatások létrehozásához, mindezt valós időben. Ha a háztartások felé fordulunk, ott pedig a mindennapokban használt eszközeinket rákapcsolhatjuk az internetre, így távolról irányíthatjuk, elektronizálhatjuk és automatizálhatjuk a folyamatokat. Például okos házak, okos kávéfőző, okos villanykörte, egyszóval minden smart eszköz ide tartozik. Ennek lényege a fokozott kényelem, használhatóság és karbantarthatóság.

- Felhasználói élmény: Fontos a rendszer felhasználókra gyakorolt hatása, a benyomás, amelyet a program kelt. Ezért törekedni kell arra, hogy a szoftver jól átlátható, használható, logikusan elrendezett nézeteket jelenítsen meg.

- Elemzések: Az adatok tárolása kiemelkedő fontosságú, mivel a rögzített információk alapján lehet következtetéseket levonni, a jövőt illető feltevéseket megfogalmazni. Az elemzések során választ kaphatunk akár a következő (hasonló/ugyanolyan) hiba leggyorsabb megoldásának menetére.

- Tesztesetek tervezése: Egy alkalmazás fejlesztéséhez hozzátartozik a program egyes részeinek a tesztelése. Ideális esetben a szoftver kódja lefedettségének maximalizálására kell törekedni, minden funkció, modul, felhasználói felület le legyen tesztelve.

\section{Projekt ütemterve:}

Egy projekt esetében fontos a tervezés és a megvalósítás időintervallumának betartása, ahhoz, hogy a projektcél a kitűzött határidőre teljesüljön. Ennek egyik lehetséges módszere az ütemterv készítése, amely koordinálja a projekt futását. [4]

Az applikáció valós elkészültének lehetséges időbeosztása

- Technológiák felkutatása: Jellemzően időigényes folyamat. A programoknak, technológiáknak és minden olyan egyéb eszköznek a megismerése, amelyre a projekt megvalósítása során szükség lesz.

- Tervezés: A technológiák felkutatásának utolsó felében már el kell kezdeni az alkalmazás tervezését. Át kell gondolni a szekvenciát, amin keresztül a felhasználó végigmegy, és azt modellezni szükséges a vizuális élmény fokozása érdekében. 
- Felhasználói felület: A tervezés során megalkotott alkalmazások, képernyőképek nagyon sokat segíthetnek a felhasználói felület kialakításában. Ez alkotja az alkalmazás keretét, ami később feltölthető mögöttes adatbázissal és adatokkal, amit a funkciók implementálásával nyerünk ki. Időben a tervezés fázisának végétől indul el, és mérhetően kevesebb erőforrást igényel a felület létrehozása.

- Alkalmazásintegráció: Kezdetben a felhasználói felület tesztadatokkal fut annak érdekében, hogy minden elem elérhető és kipróbálható legyen. Ennek a „kijavítása” érdekében ebben a lépésben a legacy alkalmazásokkal való kommunikációt valósítják meg. A két alkalmazás közötti integráció első fele ezzel teljesül. A felhasználói felület kialakításához hasonló az időigénye.

- Adatbázis kialakítása: Az integrációval létrejövő kommunikációból érkező adatokkal ki kell bővíteni, ehhez létre kell hozni egy adatbázist. A szükséges attribútumok megállapítása és az alkalmazással való összekötése.

- Ticketing alkalmazás integrálása: A fejlesztés utolsó lépése az integráció másik „végének” bevonása.

- Kódrefaktorálás + dokumentáció: Abban az esetben, amikor minden funkcionalitás múködik, még néhány implementáció részleten érdemes szépíteni, a kódot tisztábbá, olvashatóbbá kell tenni. Emellett a dokumentálás is elkezdődik, ami a projekt egyik legfontosabb része. Megalkotásával eljutunk arra a szintre, hogy ellehet kezdeni a tesztelést.

- Tesztelés: A fejlesztés utolsó szakasza.

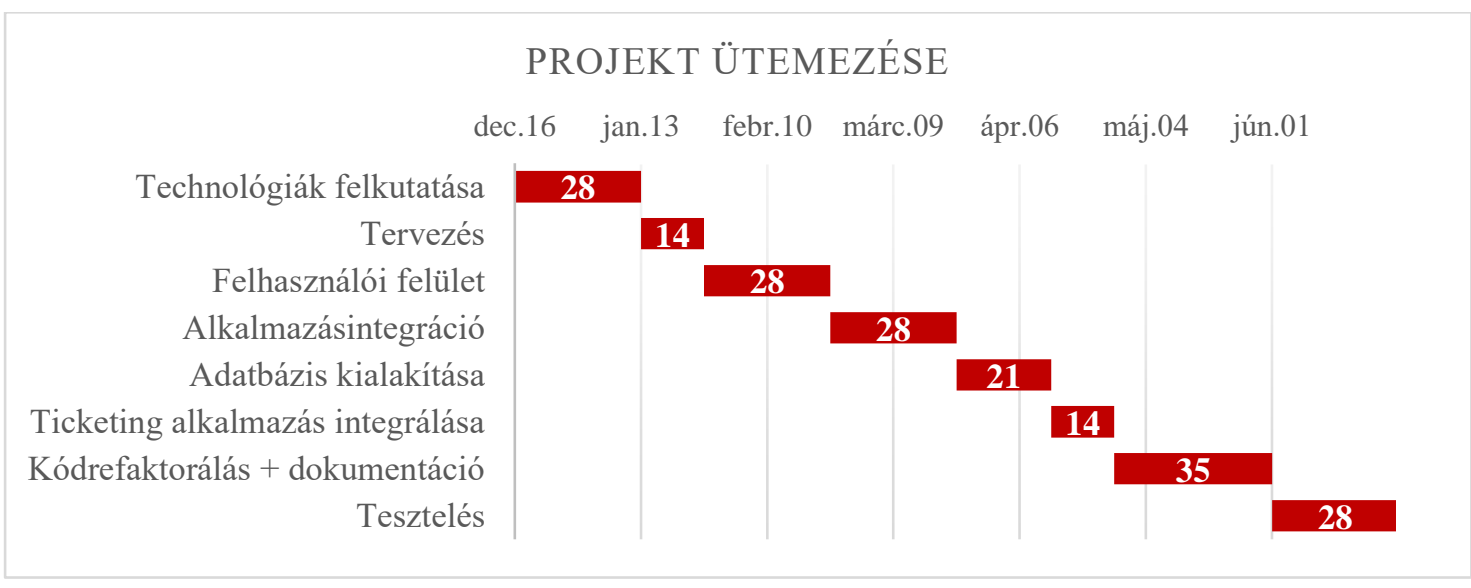

2. ábra. Projekt ütemezése

Saját forrás: Ticketing rendszerben rejlő lehetőségek - hibakezelő szoftver létjogosultsága a digitalizáció korában

\section{Teljesítményproblémák és skálázhatóság}

A hibakezelést illetően a legnagyobb akadály abban rejlik, hogy a felhasználók nem szeretnek időt tölteni a ticket-ek feladásával amennyiben az adott, szóban forgó eszköz megjavítása számukra nem létszükséglet. Ekkor inkább keresnek egy másik, ugyanazt vagy hasonló igényeket kielégítő eszközt. Valamint, ha mindenki mindenről feladna egy ticketet, akkor az olyan adminisztrációs és egyéb plusz feladatokkal járna, ami feleslegesen vennék el az időt más, sokkal hasznosabb és értékteremtő tevékenységtől. Másik problémás eset, amikor a felhasználók nem tudják pontosan definiálni és kategorizálni a problémát, így gyakorlatilag hibásan adnak fel ticketeket. Ezért mindenképpen egy felhasználó-támogató megoldást kell találni, ami meggyorsítja az egész folyamatot, és kevesebb hibával (hibamentesen) kivitelezi. A probléma megoldásának széles skálája lelhető fel a különböző szakmai lapokban, esettanulmányokban. A trend azt mutatja, hogy nélkülözhetetlen az innováció, a problémák különböző irányokból történő megközelítése, ami felkelti az érdeklődést, motivációt [3]. Ezért fontos, hogy a felhasználókat érintő üzleti folyamatokat időnként felülvizsgáljuk és a kevésbé gördülékenyen múködő tevékenységeket átgondoljuk. 
A skálázhatóság azt jelenti, hogy hogyan tudjuk a szoftver terhelni, bővíteni, nagyobb megterhelés alá tenni, hogy ne idézzen elő negatív teljesítményváltozást. Ez a kérdéskör újabb kérdőjelek felé irányít minket, mivel bekapcsolódik az integráció, mint funkció. Az integráció, ahogy korábban említettük, két vagy több rendszert kapcsol össze egymással. Ha a szoftverünk ekképpen valósul meg, úgy a skálázhatóságot jelentősen befolyásolhatja a legacy rendszerek terhelhetősége, amelynek feltérképezése körülményesség válhat. A számvitelre „lefordított” alkalmazás, mivel akár a számlákon, akár a szerződéseken alapul, sokkal nagyobb számban fordulnak elő, mint egy vállalatnál bekövetkező technikai rendellenességek, így eleve figyelni kell a kapacitásra a rendszer tervezésékor.

\section{A rendszer alkalmazhatósága - dokumentum és költségmenedzsment}

A ticketing rendszer a vállalkozás számos területén alkalmazható. A pénzügy és a számvitel területén a legelterjedtebb a dokumentumok (számlák, szerződések stb.) nyomon követése mellett a költségek, bevételek állandó monitorozása.

Adminisztrációs és vezetői szempontból is nélkülözhetetlenné válnak a folyamatok azonnali lekérdezése, amelynek két tipikus formája a dokumentum és költségmenedzsment területe ma már egyre elterjedtebb.

- dokumentum menedzsmentet: A dokumentumok elektronikus tudásbázissá alakítását jelenti, amely lehetővé teszi azok elektronikus archiválását, továbbá azok visszakeresését. Megfelelő programozással lehetőséget biztosít arra is, hogy a dokumentumokat típusuktól függően mappákba rendezze, továbbá az optikai karakterfelismerések révén metaadatok (számla sorszáma, vevők, szállítók stb.) kinyerésére is alkalmasak. A rendszer segítségével ellenőrizni tudjuk, hogy a szerződés szerinti teljesítés igazolás megtörtént-e, a számla pontosan hol, kinél vár aláírásra. Ezek az intelligens dokumentumkezelési rendszerek vállalati mérettől függetlenül alkalmazhatóak [8]

- költségmenedzsment: A költségek vállalati igény szerinti bontását (költségnemek, költséghelyek szerint stb.) továbbá azok visszakeresését teszi lehetővé. A menedzsment számára a folyamatos nyomon követés lehetőséget biztosít az esetleges azonnali beavatkozásra.

A hétköznapi életben az online értékesítéskor már találkozhatunk hasonló megoldásokkal, ahol mind a szállító, mind a vevő pontos képet kap a rendelés útjáról, a megrendelés jóváhagyásától, a számla kiállításán és kifizetésén keresztül a termék kiszállításáig. Ahogy az online szolgáltatások esetén az ügyfél végig tudja követni a megrendelt termék útvonalát, ugyan ez a folyamat a vállalkozáson belül számos területen érvényesíthető, a vállalkozás nagyságától, tevékenységi körétől függően.

\section{5. Összefoglalás}

A 2020-ban kialakult világjárvány alapjaiban változtatta meg a vállalkozások múködését. A digitalizáció eltérő szinten, de valamennyi vállalkozásnál fejlesztésre került. A kérdés az, hogy a „kényszer” digitalizációból mi az, amit a vállalkozások a továbbiakban is fenntartanak. A további fejlesztésekre mennyire nyitottak, és tudnak-e minderre erőforrásokat elkülöníteni. $\mathrm{Az}$ anyagi erőforrások előteremtése mellett komoly dilemmát okoz, hogy ehhez milyen szervezeti átalakításokra van szükség.

\section{Irodalomjegyzék}

[1] Abbott, M. L., \& Fisher, M. T. (2009). The art of scalability: Scalable web architecture, processes, and organizations for the modern enterprise. Pearson Education.

[2] Pande, P. S., \& Holpp, L. (2001). What is six sigma?. McGraw-Hill Professional. 
[3] Proctor, T. (2018). Creative problem solving for managers: developing skills for decision making and innovation. Routledge.

[4] Schwalbe, K. (2008). Information Technology Project Management, Reprint. Cengage Learning.

[5] Szóka, K. (2018). The changing controlling - expectations and changes in the context of Industry 4.o. In: Zéman, Z; Magda, R (szerk.) Controller Info Studies II. Budapest, Magyarország: Copy \& Consulting Kft. 4759.

[6] Szóka, K. (2019). Controlling riportok jelene és jövője - különös tekintettel az Ipar 4.o kihívásaira. In: Resperger, Richárd; Czeglédy, Tamás (szerk.) Modern gazdaság, okos fejlődás nemzetközi tudományos konferencia. Konferenciakötet, Sopron, Magyarország: Soproni Egyetem Kiadó, 341-348.

[7] Wannes, A., \& Ghannouchi, S. A. (2019). KPI-Based Approach for Business Process Improvement. Procedia Computer Science, 164, 265-270.

[8] https://graphax.hu/irodai-alkalmazas/dokumentum-menedzsment/

[9] Hegedưs, M. (2014): A csalás motivációi és hatása a kis- és középvállalkozói szektorban TAYLOR: GAZDÁLKODÁS- ÉS SZERVEZÉSTUDOMÁNYI FOLYÓIRAT: A VIRTUÁLIS INTÉZET KÖZÉP-EURÓPA KUTATÁSÁRA KÖZLEMÉNYEI 6 : 1-2 No. 14-15 pp. 562-571. , 10 p. (2014) 